\title{
The Effect of Altitude Difference on Physical and Mechanical Properties of Scots Pine Wood Grown in Turkey - Sinop Province
}

\section{Utjecaj nadmorske visine staništa na fizikalna i mehanička svojstva drva običnog bora u turskoj pokrajini Sinop}

Preliminary paper • Prethodno priopćenje

Received-prispjelo: 3. 5. 2015.

Accepted-prihvaćeno: 6. 9. 2016.

UDK: $630 * 812 ; 674.032 .475 .442$

doi:10.5552/drind.2016.1524

\begin{abstract}
In this study, the effect of altitude difference on the physical and mechanical properties of Scots pine (Pinus sylvestris L.) wood was investigated. For this purpose, nine Scots pine trees were selected from three altitudes: $250 \mathrm{~m}$ (low altitude), $700 \mathrm{~m}$ (intermediate altitude), and $1200 \mathrm{~m}$ (high altitude) located in the forestry of Sinop province (Black Sea Region in Turkey). For the physical properties of wood: air and oven dry specific gravity were determined, and for the mechanical properties of wood: compression strength parallel to the grain, static bending strength and modulus of elasticity in static bending were determined. Moreover, the variation of all wood properties was determined related to the altitude difference. The results of statistical analyses showed that the altitude difference was an important factor influencing the physical and mechanical properties of Scots pine wood. The air and oven dry density, compression strength parallel to the grain, static bending strength and modulus of elasticity in static bending were higher at intermediate altitude than at other altitudes.
\end{abstract}

Keywords: Scots pine (Pinus sylvestris L.), altitude difference, site, physical properties of wood, mechanical properties of wood

SAŽETAK・U radu su prikazani rezultati istraživanja utjecaja nadmorske visine staništa na fizikalno-mehanička svojstva drva običnog bora (Pinus sylvestris L.). Za istraživanje je odabrano devet stabala običnog bora u šamama pokrajine Sinop (u crnomorskoj regiji Turske) s lokacija različite nadmorske visine: $250 \mathrm{~m}$ (mala nadmorska visina), $700 \mathrm{~m}$ (srednja nadmorska visina) i $1200 \mathrm{~m}$ (velika nadmorska visina). Od fizikalnih svojstava u istraživanju je određena gustoća drva u zrakosuhom i apsolutno suhom stanju, a od mehaničkih svojstava određene su tlačna čvrstoća paralelno s vlakancima, statička čvrstoća na savijanje i modul elastičnosti pri statičkom savijanju. Varijacije svih spomenutih svojstava drva određene su s obzirom na visinske razlike lokacija s kojih su uzorci uzeti. Rezultati statističke analize pokazali su da je nadmorska visina staništa važan čimbenik koji utječe na fizikalnomehanička svojstva drva običnog bora. Vrijednosti gustoće drva u prosušenom i apsolutno suhom stanju, tlačne čvrstoće paralelno s vlakancima, statičke čvrstoće na savijanje i modul elastičnosti u statičkom savijanju bili su najveći za uzorke uzete s lokacije na srednjoj nadmorskoj visini.

Ključne riječi: obični bor (Pinus sylvestris L.), visinska razlika, lokacija, fizikalna svojstva drva, mehanička svojstva drva

Authors are associate professors at Bartin University, Faculty of Forestry, Department of Forest Industry Engineering, Turkey.

Autori su izvanredni profesori Sveučilišta u Bartinu, Šumarski fakultet, Turska. 


\section{INTRODUCTION}

\section{UVOD}

Scots pine, which has the largest geographical distribution among pine species, covers a rather large natural area of approximately $3700 \mathrm{~km}$ in width and $14700 \mathrm{~km}$ in length in Europe and Asia (EUFOGEN, 2016). Scots pine has the largest distribution area after Calabrian pine and Black pine in Turkey. It is one of the most used Pine species in silvicultural works. It starts from the east of Eskisehir, encompasses the upper parts of the North Anatolian Mountains eastward and passes to Caucasus in Turkey (GDF, 2007).

Environmental factors can be classified as physiographic factors (altitude, aspect, slope, and side slope), climatic factors (light intensity, temperature, air humidity, precipitation, and wind), edaphic factors (soil characteristics), and biotic factors (humans, animals, plants, and microorganisms) (Cepel 1995). The effects of altitude difference on forest plants have been discussed in many studies (Brazier 1977, Kiaei and Samariha, 2011; Hosseini 2006; Kiaei, 2012; Schweingruber, 2007). The physical and mechanical properties of the Scots pine were studied according to several factors (resonance frequency and ultrasonic techniques, main and normal cutting forces, industrial sawing, heattreatment, finishing, photodegradation, thermal blending with plastics, etc.) in various studies (Yörür, 2016, Zborowska et al. 2015; Budakçı and Karamanoğlu, 2014; Pelit et al. 2014; Lehto et al. 2014; Wang et al. 2014; Hassan et al. 2013; Ulker et al. 2012; Porankiewicz et al. 2011; Ghosh et al. 2009). However, there are no studies on the effect of altitude difference on the physical and mechanical properties of the Scots pine.

The aim of this study is primarily to compare some physical and mechanical properties of the Scots pine wood obtained from different altitudes. Afterwards, if gained findings show a statistically significant difference, the aim will be to determine which altitudes are the most suitable in terms of these properties. Finally, the aim of this study is to investigate the effects of altitude on the quality of wood. The outcome expected at the end of the study is to contribute to the research on the use of timber with minimum loss and optimum yield, considering the fact that misused timber leads to great economic losses based on the increasing importance of wooden material.

\section{MATERIALS AND METHODS 2. MATERIJALI I METODE}

Wood formation is affected by many factors, such as climate, site, environment, stand conditions, management, genetics and age (Zobel and van Buijtenen, 1989). Therefore, trees were selected in homogenous conditions such as soil (sandy), age (35), directions (North), tree height (15-17 m), diameter (26-28 $\mathrm{cm}$ ), and the same macroscopic properties such as latewood, annual ring/fiber orientation, and non-defects. All the trees in the stand were dominant. One disk, 5 $\mathrm{cm}$ thick, was collected from each tree at breast height for evaluation of physical properties. Test samples from mature wood with 15-30 rings were prepared according to the standard ISO 3129 (1975).

Study material originates from nine trees of $\mathrm{Pi}$ nus sylvestris L. sampled from three different altitude classes of the Sinop province in the north of Turkey. These altitude classes are 250 meter (low altitude), 700 meter (intermediate altitude), and 1200 meter (high altitude). Disks and logs were taken from the trunk 1-2 m in height to determine various wood properties.

Test samples obtained from the lumber were prepared at a sawmill located at the Forestry Faculty of Bartin University, in Turkey. Sampling methods and general requirements for the physical and mechanical tests of the lumber were carried out based on ISO 3129 (1975). The lumber was planed with a knife angle of $45^{\circ}$, and then small clear specimens were cut with the dimensions $20 \times 20 \times 30 \mathrm{~mm}(\mathrm{~L} \times \mathrm{W} \times \mathrm{H})$ for density measurements; these were taken according to the ISO 3130 (1975) and ISO 3131 (1975). Bending strength was conducted on the samples with the dimensions 20 x 20 x $360 \mathrm{~mm}$ according to the ISO 3133 (1975), and elasticity modulus in bending was done on the samples with the dimensions $20 \times 20 \times 360 \mathrm{~mm}$ according to ISO 3349 (1975). The compression strength was done on the samples with the dimensions $20 \times 20 \times 30 \mathrm{~mm}$ according to the ISO 3787 (1976). After the samples were prepared, physical (oven-dry and air-dry density), mechanical tests (bending strength and elasticity in bending and brittleness) were conducted.

All parameters were analyzed using multiple comparisons and analysis of variance (ANOVA). Significant differences between the mean values of samples were evaluated using Duncan's Multiple Range Test. Measurements obtained from the ANOVA tests, mean, standard deviation, variance, minimum, and maximum values were calculated using the SPSS 10.1 computer software program (IBM, USA). Significance was accepted at $P<0.05$.

\section{RESULTS AND DISCUSSION}

\section{REZULTATI I RASPRAVA}

This research examined the effect of altitude variation on physical and mechanical properties of Scots pine wood in Sinop province (Black Sea Region in Turkey). The results of research showed that altitude index had a significant influence on physical and mechanical properties of wood. In order to determine the relationship between the experimental variable (altitude parameters) and physical properties of wood, all the data measured were subjected to an analysis of variance and Duncan's mean separation test. Table 1 shows the results of variance analysis and Duncan's mean separation test for the physical properties of wood. ANOVA and Duncan's Multiple Range Tests showed that there were significant differences between physical and mechanical results according to various altitudes. According to the density results, the mean value of air-dry density in low altitude is $0.504 \mathrm{~g} / \mathrm{cm}^{3}$, in intermediate altitude $0.683 \mathrm{~g} / \mathrm{cm}^{3}$, and in high alti- 
..... Kaygin, Esnaf, Aydemir: The Effect of Altitude Difference on Physical and Mechanical...

Table 1 Results of variance analysis and Duncan's mean separation test for physical properties of wood

Tablica 1. Rezultati analize varijance i Duncanova testa odvajanjem srednjih vrijednosti za fizikalna svojstva drva običnog bora

\begin{tabular}{|c|c|c|c|}
\hline \multirow{2}{*}{$\begin{array}{l}\text { Altitude, } \mathbf{m} \\
\text { Nadmorska visina, } \mathrm{m}\end{array}$} & \multirow{2}{*}{$\begin{array}{c}\text { Statistical values } \\
\text { Statističke vrijednosti }\end{array}$} & \multicolumn{2}{|c|}{ Density, $\mathbf{g} / \mathrm{cm}^{3} /$ Gustoća, $\mathrm{g} / \mathrm{cm}^{3}$} \\
\hline & & Air-dry / Zrakosuho stanje & Oven-dry / Apsolutno suho stanje \\
\hline \multirow{4}{*}{250 (low/nisko) } & $x$ & $0.504( \pm 0.04)$ & $0.479( \pm 0.04)$ \\
\hline & min. & 0.416 & 0.401 \\
\hline & $\max$. & 0.640 & 0.619 \\
\hline & Cov. & 8.4 & 8.7 \\
\hline \multirow{4}{*}{700 (intermediate/srednje) } & $x$ & $0.683 *( \pm 0.07)$ & $0.634 *( \pm 0.07)$ \\
\hline & min. & 0.600 & 0.570 \\
\hline & $\max$. & 0.962 & 0.733 \\
\hline & Cov. & 10.6 & 10.9 \\
\hline \multirow{4}{*}{1200 (high/visoko) } & $x$ & $0.491( \pm 0.02)$ & $0.443( \pm 0.02)$ \\
\hline & $\min$. & 0.436 & 0.391 \\
\hline & $\max$. & 0.537 & 0.483 \\
\hline & Cov. & 3.7 & 3.6 \\
\hline
\end{tabular}

$X$ - Mean / srednja vrijednost; $\pm \mathrm{s}$ - Standard Deviation / standardna devijacija; Min. - Minimum values / minimalne vrijednosti; Max. Maximum values / maksimalne vrijednosti; $\operatorname{Cov}(\%)$ - Coefficient of variation / koeficijent varijacije; $\mathrm{N}$ - number of samples used in each test / broj uzoraka upotrijebljen u svakom testu; * significantly difference at $95 \%$ confidence level $(p<0.05)$ / značajna razlika pri razini pouzdanosti $95 \%(p<0,05)$.

tude $0.436 \mathrm{~g} / \mathrm{cm}^{3}$. The oven-dry density results in low altitude were $0.479 \mathrm{~g} / \mathrm{cm}^{3}$, in intermediate altitude $0.634 \mathrm{~g} / \mathrm{cm}^{3}$, and in high altitude $0.443 \mathrm{~g} / \mathrm{cm}^{3}$. Both the oven-dry and air-dry density value in intermediate altitude was determined to be higher than other altitudes.

In a study, Krzysik (1978) notified that spruce wood density increases with increasing altitude. However, in another study, Kiaei and Samariha (2011) investigated the effects of altitudes on density of Pinus Eldarica Medw, and the results showed that the density for the intermediate altitude was higher than for other altitudes. They explained that the reason for these changes could be ascribed to the tracheid cell wall thickness measured for each altitude index. The results obtained by Kiaei and Samariha (2011) were seen to be similar with the values of density in this study.

Relationship between air-dry density and ovendry density is shown in Figure 4 for each altitude class. There are positive correlations between air-dry and oven-dry density. However, correlation coefficients between these properties in intermediate altitude are higher than in other altitudes. Table 2 shows the results of variance analysis and Duncan's mean separation test for the mechanical properties. ANOVA and Duncan's Multiple Range Tests showed that there were significant differences between the values. According to Table 2, the mean value of compression strength in low altitude is $47.14 \mathrm{~N} / \mathrm{mm}^{2}$, in intermediate altitude 64.81 $\mathrm{N} / \mathrm{mm}^{2}$, and in high altitude $44.16 \mathrm{~N} / \mathrm{mm}^{2}$, respectively. As seen, the compression strength value in intermediate altitude is higher than in other altitudes. According to the values of bending strength results, it was $79.533 \mathrm{~N} / \mathrm{mm}^{2}$ in low altitude, $134.210 \mathrm{~N} / \mathrm{mm}^{2}$ in intermediate altitude and $77.868 \mathrm{~N} / \mathrm{mm}^{2}$ in high altitude. Obviously, the bending strength value in intermediate altitude is higher than in other altitudes.

Mean value of modulus of elasticity in static bending is $8515 \mathrm{~N} / \mathrm{mm}^{2}$ in low altitude, $17383 \mathrm{~N} / \mathrm{mm}^{2}$

Table 2 Results of variance analysis and Duncan's mean separation test for mechanical properties of wood

Tablica 2. Rezultati analize varijance i Duncanova testa odvajanjem srednjih vrijednosti za mehanička svojstva drva običnog bora

\begin{tabular}{|c|c|c|c|c|}
\hline $\begin{array}{l}\text { Altitude, } \mathbf{m} \\
\text { Nadmorska visina, m }\end{array}$ & $\begin{array}{c}\text { Statistical values } \\
\text { Statističke } \\
\text { vrijednosti }\end{array}$ & $\begin{array}{c}\text { Compression strength } \\
\text { Tlačna čvrstoća } \\
\mathrm{N} / \mathrm{mm}^{2}\end{array}$ & $\begin{array}{c}\text { Bending strength } \\
\text { Čvrstoća na savijanje } \\
\mathrm{N} / \mathrm{mm}^{2}\end{array}$ & $\begin{array}{c}\text { Modulus of elasticity } \\
\text { Modul elastičnosti } \\
\mathrm{N} / \mathrm{mm}^{2}\end{array}$ \\
\hline \multirow{4}{*}{250 (low/nisko) } & $x$ & $47.14 *( \pm 8.85)$ & $79.53 *( \pm 12.22)$ & $8515 *( \pm 2562)$ \\
\hline & $\min$ & 39.14 & 49.08 & 3114 \\
\hline & $\max$. & 62.71 & 91.16 & 10913 \\
\hline & $\operatorname{cov}$ & 18.79 & 15 & 30.08 \\
\hline \multirow{4}{*}{$\begin{array}{l}700 \text { (intermediate/ } \\
\text { srednje) }\end{array}$} & $x$ & $64.81 *( \pm 4.29)$ & $134.21 *( \pm 21.82)$ & $17383 *( \pm 2944)$ \\
\hline & $\min$. & 58.11 & 85.73 & 11651 \\
\hline & $\max$ & 70.06 & 155.58 & 20315 \\
\hline & $\operatorname{cov}$ & 6.62 & 25 & 16.94 \\
\hline \multirow{4}{*}{1200 (high/visoko) } & $x$ & $44.16 *( \pm 3.55)$ & $77.87 *( \pm 13.95)$ & $10389 *( \pm 1580)$ \\
\hline & $\min$. & 39.31 & 53.28 & 8561 \\
\hline & $\max$. & 49.88 & 99.80 & 12645 \\
\hline & $\operatorname{cov}$ & 8.04 & 17 & 15.20 \\
\hline
\end{tabular}

$X$ - Mean / srednja vrijednost; $\pm \mathrm{s}-$ Standard Deviation / standardna devijacija; Min. - Minimum values / minimalne vrijednosti; Max. Maximum values / maksimalne vrijednosti; Cov (\%) - Coefficient of variation / koeficijent varijacije; $\mathrm{N}$ - number of samples used in each test / broj uzoraka upotrijebljen u svakom testu; * significantly difference at $95 \%$ confidence level $(p<0.05)$ / značajna razlika pri razini pouzdanosti $95 \%(p<0,05)$. 
in intermediate altitude, and $10389 \mathrm{~N} / \mathrm{mm}^{2}$ in high altitude. Similarly, bending strength value in intermediate altitude is higher than in other altitudes (low and high altitude). The results of statistical analyses showed that the altitude difference was an important factor influencing the mechanical properties of Scots pine. These differences in wood properties have been reported by Bektas et al. (2003) and Keiaei and Samariha (2011).

\section{CONCLUSIONS}

4. ZAKLJUČAK

The results indicate that there is an important relationship between the physical and mechanical properties of Scots Pine wood and the altitude.

1. According to the properties of density, which is considered an important indicator of wood quality, middle altitude $(700 \mathrm{~m})$ can be suggested as the most suitable height for plantations of Scots Pine in future silviculture plans to be realized in the in the region.

2. Compression strength, static bending strength and modulus of elasticity in static bending are higher in intermediate altitude than in other altitude classes.

3 . According to this result, when making wooden constructions, bridges, boats and furniture supporting parts, optimum benefit will be gained by using timber obtained from the middle altitude, instead of low $(250 \mathrm{~m})$ and high $(1200 \mathrm{~m})$ altitudes. In this way, potential economic losses will be prevented. This study has been made for one tree species and one region and provides a base for further studies of other tree species and their growing areas in Turkey and worldwide. As a result, it can be said that the quality of timber provided from low and high altitude will be lower than the quality of timber from middle altitude. Timber from the middle altitude can be recommended.

\section{Acknowledgements - Zahvala}

Financial support from Bartin University (The support programme for scientific research projects, Project no. BAP-2012-2-72) is gratefully acknowledged.

\section{REFERENCES}

5. LITERATURA

1. Bektas, I.; Alma, H.; M.; As, N.; Gundogan, R., 2003: Relationship between site index and several mechanical properties of Turkish Calabrian pine (Pinus brutia Ten). Forest Product Journal, 53 (2): 1-5.

2. Brazier, J. D., 1977. The effect of forest practices on quality of the harvested crop. Forestry, 50 (1): 49-66. http://dx.doi.org/ 10.1093/forestry/50.1.49.

3. Budakçı, M.; Karamanoğlu, M., 2014: Effect of bleaching on hardness, gloss, and color change of weathered woods. BioResources, 9 (2): 2311-2327. http://dx.doi.org/10.15376/biores.9.2.2311-2327.

4. Cepel, N., 1995: Orman Ekolojisi. İstanbul, Turkey: İstanbul University (in Turkish).

5. EUFOGEN, 2016: European Forest Genetic Resources Programme, Regeneration of Scots Pine. http://www.eu- forgen.org/fileadmin/templates/euforgen.org/upload/ Documents/Maps/JPG/Pinus_sylvestris.jpg.

6. Ghosh, S. C.; Militz, H.; Mai, C., 2009: Natural weathering of Scots pine (Pinus sylvestris L.) boards modified with functionalized commercial silicone emulsions. BioResources, 4 (2): 659-673.

7. Govorčin, S.; Sinković, T.; Trajković, J., 2003: Some physical and mechanical properties of beech wood grown in Croatia. Wood Res-Slovakia, 48: 39-52.

8. Hassan, K. T. S.; Horáček, P.; Tippner, J., 2013: Evaluation of stiffness and strength of Scots pine wood using resonance frequency and ultrasonic techniques. BioResources, 8 (2): 1634-1645. http://dx.doi.org/10.15376/biores.8.2.1634-1645.

9. Hossein, S. Z., 2006: The Effect of Altitude on Juvenile Wood Formation and Fiber Length, a Case Study in Iranian Beech wood (Fagus orientalis L.). J. Agric. Sci. Technol., 8: 221-231. http://dx.doi.org/10.15376/biores.9.4.7382-7388.

10. Keiaei, M.; Samariha, A., 2011: Relationship between altitude index and wood properties of Pinus eldarica medw (Case study in north of Iran). GU J Sci, 24 (4): 911-918.

11. Kiaei, M., 2012: Effect of site and elevation on wood density and shrinkage and their relationships in Carpinus betulus. For. Stud. China, 14 (3): 229-234. http://dx.doi.org/10.1007/s11632-012-0310-3.

12. Krzysik, F., 1978: Wood Science. Warsaw, 653 pp.

13. Lehto, J.; Alén, R.; Malkavaara, P., 2014: Multivariate correlation between analysis data on dissolved organic material from Scots Pine (Pinus sylvestris) chips and their autohydrolysis pre-treatment condition. BioResources, 9 (1): 93-104. http://dx.doi.org/10.15376/biores.9.1.93-104.

14. Pelit, H.; Sönmez, A.; Budakç1, M., 2014: Effects of thermowood ${ }^{\circledR}$ process combined with thermo-mechanical densification on some physical properties of Scots Pine (Pinus sylvestris L.). BioResources, 9 (3): 4552-4567. http://dx.doi.org/10.15376/biores.9.3.4552-4567.

15. Porankiewicz, B.; Axelsson, B.; Grönlund, A. A.; Marklund, B., 2011: Main and normal cutting forces by machining wood of Pinus sylvestris. BioResources, 6 (4): 3687-3713.

16. Schweingruber, F. H., 2007: Wood Structure and Environment. Syracuse, New York: Springer-Verlag.

17. Ulker, O.; Imirzi, O.; Burdurlu, E., 2012: The effect of densification temperature on some physical and mechanical properties of Scots pine (Pinus sylvestris L.). BioResources, 7 (4): 5581-5592. http://dx.doi.org/10.15376/biores.7.4.5581-5592.

18. Wang, S.; Xie, B.; Cheng, Q.; Via, B.; Xu, M.; Zhao, H., 2014: The influence of repeated thermal shock on the mechanical properties of Mongolia Scots Pine and Moso Bamboo. BioResources, 9 (4): 7382-7388. https://doi.org/10.15376/biores.9.4.7382-7388.

19. Zborowska, M.; Stachowiak-Wencek, A.; NowaczykOrganista, M.; Waliszewska, B.; Prądzyński, W., 2015: Analysis of photodegradation process of Pinus sylvestris L. wood after treatment with acid and alkaline buffers and light irradiation. BioResources, 10 (2): 2057-2066. https://doi.org/10.15376/biores.10.2.2057-2066

20. Yorur, H. (2016). Utilization of Waste Polyethylene and its Effects on Physical and Mechanical Properties of Oriented Strand Board. BioResources, 11 (1)): 2483-2491.

21. Zobel, B. J.; van Buijtenen, J. P., 1989: Wood Variation: Its Causes and Control. Berlin, Heidelberg, New York: Springer-Verlag.

https://doi.org/10.1007/978-3-642-74069-5 
..... Kaygin, Esnaf, Aydemir: The Effect of Altitude Difference on Physical and Mechanical...

22. ***ISO 3129, 1975: Wood. Sampling methods and general requirements for physical and mechanical tests. International Organization for Standardization, Geneva, Switzerland.

23. ***ISO 3130, 1975. Wood. Determination of moisture content for physical and mechanical tests. International Organization for Standardization, Geneva, Switzerland.

24. ***ISO 3131, 1975: Wood. Determination of density for physical and mechanical tests. International Organization for Standardization, Geneva, Switzerland.

25. ${ }^{* * *}$ ISO 3133, 1975: Wood. Determination of ultimate strength in static bending. International Organization for Standardization, Geneva, Switzerland.

26. ***ISO 3349, 1975: Wood. Determination of modulus of elasticity in static bending. International Organization for Standardization, Geneva, Switzerland.
27. ***ISO 3787, 1976: Wood. Determination of ultimate stress in compression parallel to grain. International Organization for Standardization Geneva, Switzerland.

\section{Corresponding address:}

Assoc. Prof. DENIZ AYDEMIR, Ph.D.

Bartin University

Faculty of Forestry, Forest Industrial Engineering 74100, Bartin, TURKEY

e-mail: denizoren32@yahoo.co.uk 